\title{
Recruiting Quality Academics: The Relationship of Passion, Role Model, Workplace Flexibility, and Career Decision-Making Self-Efficacy
}

\section{Jakaria Dasan}

\begin{abstract}
Consequently, this may lead to the nation aspiration of becoming higher education hub in the region. Thus, understanding individuals' interest towards pursuing academic career may lead to the recruitment of quality academics. A quantitative study was carried out involving 463 third year undergraduate students in selected universities. Passion, role model, and workplace flexibility had been found to significantly predict the intention to pursue academic career based on social cognitive career theory. In addition, career decision-making self-efficacy was found to be a significant intervening role that motivate further one's confidence in pursuing academic career. Factor analyses led to the identification of new variables which significantly predict the criterion variables. However, the strength of relationship between each variable to criterion variable differs. Passion, supportive role models, and perceived workplace flexibility were found to be significantly predicting intention to pursue academic career. On the other hand, perceived workplace flexibility was found to have less influence when compared to the other two variables. Meanwhile, career decision-making self-efficacy of assessing personal and occupational features and career decision-making self-efficacy of gathering occupational information were well reported to partially mediate the relationship of passion and supportive role models, and the criterion variable.
\end{abstract}

Keywords: quality academics, academic career intention, passion, role model, workplace flexibility, career decision-making self-efficacy

DOI : https://doi.org/ 10.30596/ijbe.v1i1.3441

JEL Classification : O, O1, 015

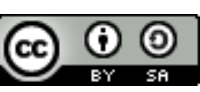

Published by IJBE, Indonesia | Copyright (C) 2019 by the Author(s) | This is an open access article distributed under the Creative Commons Attribution License http://creativecommons.org/licenses/by/4.0), which permitsunrestricted use, distribution, and reproduction in any medium, provided the original work is properly cited.

Cite this article as:

Dasan, J., (2019). Recruiting Quality Academics: The Relationship of Passion, Role Model, Workplace Flexibility, and Career Decision-Making Self-Efficacy. International Journal of Business Economics (IJBE), 1(1), 20-37. 


\section{IJBE}

International Journal of Business Economics, 1(1), 22-38, September 2019

http://jurnal.umsu.ac.id/index.php/ijbe

eISSN 2686-472X

\section{INTRODUCTION}

Once, Year 2020 as it is famously recognized as "Wawasan 2020", has become the benchmark year for Malaysia to reach its status as a fully developed nation. This is the time, where Malaysia is expected to reach its higher education height as well (Mok \& Yu, 2011; Morshidi Sirat, 2005, 2006). In other words, higher education has been recognized as one of the indicators that support Malaysia's credibility to be known as the fully developed nation. This is in line with the dogma that only higher education could well-equip human capital with necessary capacities. As a consequence, this will enable them to adapt and survive in the challenging environment (Elhag, 2011). It is also through higher education that knowledgeable and skill workforces are created. In its commitment to realize these aspirations, Malaysia has aimed high not only to become a higher education regional centre, but also to become a global education hub (Yean \& Yi, 2000). Hence, scaling up the ranking ladder, and to be amongst the best higher education providers. In order to meet this aspiration, it is essential to having quality academics.

Since the previous government, the relevant ministry has taken some strategies to fulfil this aspiration (Tham \& Kam, 2008; Ministry of Higher Education, 2007). The strategies include the introduction of Malaysian Education Blueprint (MEB) 2013-2015, and the implementation of National Higher Education Strategic Plan. The move to separate Ministry of Education and Ministry of Higher Education was another effort to act more actively than before (Singh, Kaur, Schapper \& Jack, 2013). Proactive promotion of the internationalisation of higher education through global network has strengthen further the visibility of Malaysian higher education provider (Tham \& Kam, 2008). Various achievements received including the $11^{\text {th }}$ ranked of higher education preferred destination in the world as recognized by World Education Service Report (Zulkifli Abd Rahman., 2014, April 13). The new government that took over the reign has started to make modest achievements by starting with merging back the Ministry of Education to spearhead the embark of becoming notable higher learning provider in the region.

Notwithstanding, it has been a global dilemma that staff numbers have not kept up with the heavy increase in the student population (Court, 1999). Study among UK academics found this scenario of imbalance number of the student-staff ratio had risen steadily. Similarly, Malaysia has experienced the same tendency. The enrolments of students and staff employed (Ministry of Higher Education, 2008-2017; Ministry of Education, 2018) displays the growing enrolment of international students which will add to the high expectation of existing 40 per cent of local students pursuing their higher education. Meanwhile, the constant increase of expatriate staff from 2007 to 2012 suggests that there is a demand on certain subject areas that locals could not cover. Even though the proposed ratio of 1:17 might look well (Ahmad Nurulazam Md Zain, et al., 2008) but it is not in practice across and within the public universities (IPPTN, 2006). To make matter worst, the widespread retirements in this decade which had been predicted a decade ago (Lindholm, 2004), poses as another threat to the effort of providing sufficient number of academics. In short, there is a need to recruit larger number of new faculty in the replacement of senior generation of academicians.

Understanding better how personal and contextual factors operate together to shape a direct relationship with the intention to produce quality academics can be useful in order to attract newcomers to academic profession. In other words, there is a need to investigate factors that will incite individuals' interest to academic career to achieve the aspiration of becoming global higher education hub. In other words, one's strong intention to become 


\section{IJBE}

International Journal of Business Economics, 1(1), 22-38, September 2019

http://jurnal.umsu.ac.id/index.php/ijbe

eISSN 2686-472X

academics may directly inspire one to become quality academics. Literature reviews suggest that passion, role model, workplace flexibility, and career decision-making self-efficacy could predict the intention to pursue an academic career.

\section{Intention to Pursue Academic Career}

Academic career refers to a career as academics in higher learning institutions. Academic career is known as helping profession in which personal and social experiences, as well as inspiration to serve others are identified as the important criteria (Fischman, Schutte, Solomon, \& Wu Lam, 2001). With reference to the term "intention to pursue a career," Oxford Advance Learner's Dictionary defines intention as an individual's desire to try or to achieve something over a period of time. Studies (such as Cohen \& Parsotam, 2010; Johnson et al., 2008) provided the definition on the intention to pursue a career as the subjective probability of individuals choosing to pursue a career.

Studying individuals' intention to pursue academic career, especially among those individuals below 24 years old is relevant since these individuals have yet to reach their career maturity stage (Super, 1957). Super (1957) stated that as individuals are about to reach the age of 24, they will decide on which career to pursue. The current study used the sample of undergraduate students, who get better exposure to academic career since they are in the higher learning institution already. It is high time for them to think of the career they intend to pursue toward the end of their study year (Super, 1957). Astin (1984) reported that students aspire to pursue academic career as long as the career can provide adequate income for survival needs, brings pleasure, and allows contribution through research, writing and teaching. Thus, Astin's (1984) finding revokes the idea that individual seek academic career to accumulate financial wealth. Rather, individual may pursue academic career because of the intrinsic and extrinsic motivation.

\section{Social Cognitive Career Theory}

Social cognitive career theory (SCCT) (Lent, Brown, \& Hackett, 1994; Gore \& Leuwerke, 2000) was developed as a way to understand and explain individuals' vocational interests, choices, and performance. Lent and colleagues (2002) found that SCCT was more suitable to be used in explaining career related to academia. This confirms the appropriate usage of SCCT in describing the relationship of all variables involved in this study.

Lent and colleagues $(1994,2000)$ proposed that SCCT can moderate and directly affect interests into goals, and goals to actions. Similarly, SCCT promotes the notion that career interests are regulated by self-efficacy and an outcome expectation that may form lasting interests in activities when they experience personal competency and positive outcomes. However, having less confidence with one's competency will only cause people to avoid activities. Especially, when facing barriers or receiving inadequate supports that may hamper individuals' intention to put career interest into actions. Thus, SCCT caters the idea that perceived contextual supports and lack of barriers will facilitate the realization of interest into goals, and goals into actions. It is believed that supports received from role model could ease the barriers that may block individuals' intention. In addition, government's continuous effort in making academia a conducive working environment plays a major role in attracting more individuals to academic career. In short, individual passion, better supports and lesser barriers represent personal and contextual factors that could lead to the intention to pursue a career as described by SCCT. 


\section{IJBE}

International Journal of Business Economics, 1(1), 22-38, September 2019

http://jurnal.umsu.ac.id/index.php/ijbe

eISSN 2686-472X

\section{Personal Factor of Passion}

The current study confines the meaning of the word passion to energy, desire, enthusiasm, emotion, and motivation that one puts on while pursuing academic career choice (Sumerlin \& Littrell, 2011). In view of this, passion is directly associated to what make one wants to become academician which includes one's love for ideas, love for educating others, and love for students (Fried, 2001). In academic profession, interests towards teaching, doing research, and performing service will enable anyone to succeed in the career. Various authors state that teachers' passion in teaching and knowledge develop as a result of some emotional attachment (Day, 2004; Day, et al., 2007; Elliot \& Crosswell, 2002). Emotional attachment acts as intrinsic motivation that drives personal desire and motivation. Such engagement of desire and motivation generates passion which forms a crucial link between the work and individuals' personal level of commitment (Day, 2004; Elliot \& Crosswell, 2002). A study by Norshima Zainal Shah (2008) revealed that academicians will instill good knowledge to their students if the academicians feel sensitive to the well-being of the students. As a consequence, the passionate academicians could extend the important education to the students (Norshima Zainal Shah, 2008).

There are two models of passion; namely, harmonious and obsessive (Vallerand \& Houlforth, 2003). This dualistic model of passion produces different behavioural outcomes. Harmonious passion is linked to the positive emotion, concentration and flow, while obsessive passion is associated with the development of negative emotion. According to Vallerand and Houlforth (2003), people with harmonious passion are capable of maintaining and controlling over the passionate activities. This is because they could physically and mentally disengage from the excessive work activity when needed. On the other hand, obsessive passion leads people to a rigid persistence, which may implicate negative consequences (Boice, 2000) such as, burnout (Vallerand, et al., 2010). Despite its capability to continuously energize people (Dlugos \& Friedlander, 2001), a too rigid involvement in emotionally demanding situations can also cause burnout. Burnout takes place when passion turns one into the state of physical, emotional, and mental exhaustion (Figley, 1995). Burnout occurs because one engages too much intensity in the particular activities that one neglects other important activities in life (Coulehan, 2002). Carbonneau and colleagues (2008) concluded that an increase in harmonious passion may enhance work satisfaction and reduce burnout. On the other hand, an increase in obsessive passion will only reduce work satisfaction, and lead to burnout (Carbonneau et al., 2008). Hence, it was predicted that obsessive passion may jeopardize the duration of intention, but not for harmonious passion. Consequently, hypotheses were developed as follow;

H1 : There is a significant relationship between the models of passion (harmonious and obsessive) and intention to pursue academic career.

H1.1: Harmonious passion is positively related to the intention to pursue an academic career. H1.2: Obsessive passion is negatively related to the intention to pursue an academic career.

\section{Influential Role Model}

Role models exert influence directly or indirectly (Nauta \& Kokaly, 2001; Fried \& McCleave, 2009). However, the level of influence depends on the type of relationship (Fouziah, Amla \& Ramlee, 2010). According to Fouziah and colleagues (2010), role model may influence individual's career decision through healthy relationship in which there is a direct relationship between the role model and the modeller. According to Lent and colleagues (1994), SCCT describes a direct effect of role model on career choice. As 


\section{IJBE}

International Journal of Business Economics, 1(1), 22-38, September 2019

http://jurnal.umsu.ac.id/index.php/ijbe

eISSN 2686-472X

espoused in SCCT, role model provides vicarious learning experiences that increase the tendency of individuals to choose a specific career (lent et al., 1994). This is supported by the fact that learning experiences are gained as a result of a particular teacher's influence (Goldacre et al., 2005). Anderson and Gilbride (2005) found that those who are still undecided about their future career choice could be influenced by receiving career information. This could take place if direct support is provided by role model (Nauta \& Kokaly, 2001) such as providing necessary information to enthusiast students.

Nauta and Kokaly (2001) also found that the indirect influence is adequate to assist the gathering of needed occupational information. This is because individuals would find it easier to recognize characteristics and goals that are deemed worthy for them to imitate. Quimby and DeSantis (2006), who studied the career choice of female undergraduate students, revealed that role models have a small but significant direct influence on career choice. The more the exposure given to role models, the better the female students feel in making career decision. In other words, modelling is capable of providing vicarious learning experiences that increase individuals' liking on a career (Perrone et al., 2002). In fact, the successful career achieved by role model itself will create a strong belief to others that they too could succeed in the same field as their role models (Perrone et al., 2002). Furthermore, vicarious learning may establish the required general support (Nauta \& Kokaly, 2001) which increases individuals' self-efficacy and build individuals' confidence with the career (Fieldt et al., 2010). In addition, Fried and MacCleave (2009) argued that academic career is different from other careers since academic careers involve activities of teaching, doing research, and performing community service in which individuals may learn better and faster through supportive role models (Fried \& MacCleave, 2009). Different from supportive role model, inspirational role model seems to exert strong influence among teenagers who have yet entering the university. Therefore, it was hypothesized in this study that;

$\mathrm{H} 2$ : There is a significant relationship between role models and intention to pursue academic career.

H2.1 : Supportive role model is positively related to the intention to pursue an academic career.

H2.2 : Inspirational role model is negatively related to the intention to pursue an academic career.

\section{Contextual Factor of Perceived Workplace Flexibility}

The current study also identified perceived workplace flexibility as another relevant factor that may predict individual's intention to pursue a career, especially academic career choices (Carbonneau et al., 2008). Hill (2008) defined workplace flexibility as "the ability of workers to make choices influencing when, where, and for how long they engage in workrelated tasks" (p.152). In previous researches on workplace flexibility, schedule flexibility had been identified as the core dimension of workplace flexibility. Schedule flexibility is related to autonomy of work time (Vallerand, et al., 2003) in which individuals have the autonomy or freedom to decide on their work time schedule. The phrase "as the time you start and finish work" is often used to show the management concern related to working hours since academicians are knowledge workers who know how to best execute their functions (Drucker \& Maciariello, 2004). According to Drucker (2004), knowledge workers must be autonomous, in which knowledge workers need freedom to carry out the tasks assigned. Workplace flexibility provides such freedom. For instance, academics may discuss their teaching schedule prior to faculty's endorsement. This act indicates how a flexible condition 


\section{IJBE}

International Journal of Business Economics, 1(1), 22-38, September 2019

http://jurnal.umsu.ac.id/index.php/ijbe

eISSN 2686-472X

being highly valued in academia. In addition to schedule flexibility, the other elements of workplace flexibility concerns the place of work and time that allows individuals to entertain their personal or family matters during working hours (Vallerand, et al., 2003). At far, there is no major issue concerning place of doing work in public universities in Malaysia. Meanwhile, the allowance for personal leaves, which refers to a permission given to individuals for an hour or two to tackle personal or family matters, indicate strongly the perceived workplace flexibility found in academia.

Nowadays, flexible place to do the job becomes practical in parallel with the technological advance. Workers may sometimes telecommute that allow them to work remotely. In fact, this arrangement proves that workers can still successfully accomplish their job (Hartman, 2006). Thus, while doing their work, they can also accommodate their personal or family needs. Study showed that individuals' inability to entertain both domain of work and family may cause stress leading to family work conflict (Greenhaus \& Beutell, 1985). This work-family conflict usually arises from the difficulty of adjusting working hours (Bruck, Allen, \& Spector, 2002; Spector et al., 2004). Hence, to ensure that work-family conflict can be minimized, schedule flexibility is necessary (Hill et al., 2008). Schedule flexibility allows workers to arrange their working hours according to the time based or weekly based which is known as flextime (Hill et al., 2008). Flextime, which refers to the arrangement of daily work hours, gives employees a flexible working hour as long as the employees are at work during the core hours (Maleske, 1995). Schedule flexibility is also related to personal control in scheduling when one wants to do the work including working hours and the time of days (Vallerand \& Houlfort, 2003). Having the personal control, one could manage the work-family boundary better (Bobinsky, 2009) in which one can mitigate the effect of stress as a result of having in control of their working hours, and the way they handle the related tasks (Halpern, 2005). In relation to the autonomy in deciding work time or schedule flexibility, the allowance for personal leave is also considered as an important gesture from the employer which shows that the management is care about its employees. Taking time off for an hour or two to deal with personal or family matters during working hours has been highly valued by employees (Vallerand et al., 2003). In brief, academic career needs to meet such expectation in order to attract people to pursue academic career. Therefore, the following hypothesis was proposed;

H3: Perceived workplace flexibility is positively related to the intention to pursue academic career.

\section{Intervening Effect of Career Decision-Making Self-Efficacy}

Career decision-making self-efficacy (CDMSE) investigates individuals' confidence in making career decisions (Betz, Klein, Taylor, 1996; Taylor \& Betz, 1983). CDMSE composes of five dimensions; namely, accurate self-appraisal, problem solving, planning, goal selection, and occupational information. These five dimensions represent the five competencies in the sub-scales of Career Decision-Making Self-Efficacy Scale. High efficacy on these tasks means high career decision-making self-efficacy. Individuals with higher career decisionmaking self-efficacy, may have higher career exploration behaviour and vocational identity. Study showed that students who are more confident in their ability to complete the tasks related to career decisions were more certain because they have a clear vision of their goal, strengths, and interests (Gushe, Clarke, Pantzer, \& Scanlan, 2006). Taylor and Betz (1983) revealed that career indecision among university students is due to their inability to make a 


\section{IJBE}

International Journal of Business Economics, 1(1), 22-38, September 2019

http://jurnal.umsu.ac.id/index.php/ijbe

eISSN 2686-472X

choice. On the other hand, students who were less confidence in career decision-making tasks were also less confidence in making career choices.

CDMSE had served as a significant mediator to motivate people to achieve special goals, such as pursuing a career in particular areas (Feltz \& Payment, 2005). A study on undergraduate students revealed that problem solving subscale was the most difficult task to do, while self-appraisal and occupational information subscales as the least difficult (Isik, 2010). The study also found that the older group (21 and over) scored significantly higher on goal selection, planning, self-appraisal, and occupational information subscales than younger group (20 years of age and below). In addition, CDMSE displays the ability to make careerrelated decisions in which low score on CDMSE indicates the inability in career-related decisions. Consequently, this may have an impact on students' future career plan. Furthermore, Patton and Creed (2007) found a significant correlation between CDMSE and students' career aspirations and expectations in which students who earned a high score in CDMSE scale were those students who were high in career aspirations and expectations. Thus, the five tasks of career decision making need to be at a significant score to ascertain that one is ready to make a career choice (Bakar, Zakaria, Mohamed, \& Hanafi, 2011).

Based on Baron and Kenny's (1986) mediation model, the mediating effect of career decision-making self-efficacy on the relationship between personal factor of passion, and contextual factors of role model and workplace flexibility would exist only in the presence of the following criteria: (1) the effect of passion, role model, and workplace flexibility on intention to pursue academic career is significant; (2) the effect of passion, role model, and workplace flexibility on career decision-making self-efficacy (CDMSE) is significant; and (3) when CDMSE is added to passion, role model, and workplace flexibility as an explanatory variable of intention to pursue academic career, the effect of CDMSE could be significant. The mediating effect might cause the influence of passion, role model, and workplace flexibility on academic career choice to be significantly reduced. In the case where large reduction has occurred, the effect of passion, role model, and workplace flexibility become non-significant or zero. This is the case where CDMSE could have full mediation. The following hypotheses were developed to test the mediation impact of CDMSE;

H4: Career decision-making self-efficacy tasks significantly mediate the relationship between passion, role model and perceived workplace flexibility, and intention to pursue academic career.

In the end, the hypotheses developed to the following theoretical framework;

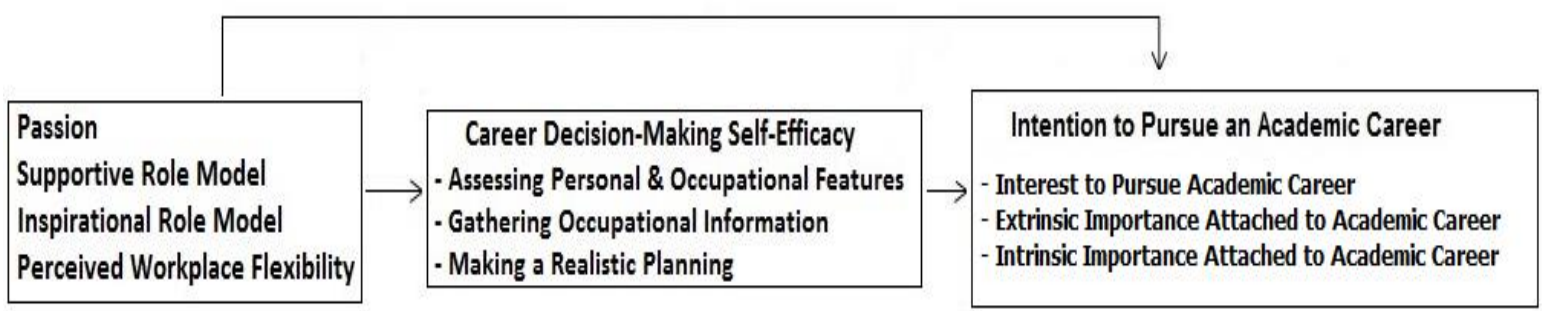

Figure 1. The Theoretical Framework 


\section{IJBE}

International Journal of Business Economics, 1(1), 22-38, September 2019

http://jurnal.umsu.ac.id/index.php/ijbe

eISSN 2686-472X

\section{RESULTS AND DISCUSSIONS}

\section{The Impact of Passion in Pursuing Academic Career}

As defined earlier, passion refers to individual's strong desire to a particular activity in which he or she is keen to invest time and energy to engage in it (Vallerand et al., 2003). Vallerand et al. (2003) identified two types of passion; namely, harmonious passion and obsessive passion. It was found that harmonious passion positively guides people to a successful outcome, while obsessive passion vice versa (Forest et al., 2011; Carbonneau et al., 2008; Vallerand et al., 2003). Nevertheless, the current study presented different views. Factor analysis led to only one dimension of passion which was termed as passion. Five items were from harmonious passion, while four items were from obsessive passion. This nine-item passion describes individuals' strong interest in pursuing academic. In addition, passion will not cause burnout (Carbonneau et al., 2008) in the case of intention to pursue academic career. Hence, no psychological adjustment needs to take place (Piasentin \& Chapman, 2006).

In contrast to Vallerand and Houlforth (2003), factor analysis revealed that intention to pursue academic career would not cause a positive (harmonious) or negative (obsessive) effect. Instead, it will indicate whether individuals will proceed in developing their passion in pursuing academic career or not interested in pursuing at all. Thus, the items that form the new variable of passion could indicate individuals' seriousness in pursuing the academic career. The Cronbach's alpha of 0.87 suggested that passion scale has a higher reliability scale. In other words, the merging of harmonious and obsessive items could form a strong measure of passion scale that is useful to investigate the effect of passion on intention to pursue academic career. In addition, passion scored a mean value of 3.21. This score implied that there is an interest among respondents on intention to pursue academic career. As a result of factor analysis, hypotheses were then modified.

\section{The Influence of Supportive and Inspirational Role Models}

The development of the new variable for role models is timely since literatures on academic career choice is still lacking (Quimby \& DeSantis, 2006; Perrone et al., 2002). The identification of the new variable could make ease the understanding of Gen-Y's career aspirations who put great emphasis on mentoring (Dries et. al., 2008; Broadbridge et al., 2007). Moreover, higher education begins to gain high demand as shown by the speedy development on more infrastructure projects related to higher education. Malaysia, itself, is in its pursuance to embark on as the competitive higher education provider in the region (Tham \& Kam, 2008; Yean \& Yi, 2007). Subsequently, due to the factor analysis, the research question which originally sought to investigate the relationship between role models and intention to pursue academic career has been changed to investigating the relationship between supportive role models and intention to pursue academic career, and the relationship between inspirational role models and intention to pursue academic career.

Supportive Role Models. Supportive role models contain seven items that suggest the availability of role models in providing direct assistance to individuals interested in pursuing academic career. The five items found in this variable refer to (1) the availability of someone in helping individuals to weigh the pros and cons of making academic career as a choice, (2) considering academic career as an option, (3) supporting in the making of academic career as a choice, (4) making academic career choice, and (5) making important career decision. Meanwhile, the remaining two items came from inspirational role models; namely, having a mentor in academic career, and having someone showing general strategies for a successful life. The development of supportive role models supports the finding made by Richardson and 


\section{IJBE}

International Journal of Business Economics, 1(1), 22-38, September 2019

http://jurnal.umsu.ac.id/index.php/ijbe

eISSN 2686-472X

Watts (2005) who claimed that supportive role models who keen to provide direct assistance will produce greater impact on one's intention.

There is a high internal consistency reliability recorded over the items in supportive role models (0.83) in which the items measuring the effect of supportive role models are considered good enough. In addition, the mean values for this variable also had a strong score of 3.62 which implied individuals' perception on the influence of someone, especially among academicians, in assisting individuals' intention to pursue academic career. In fact, among the predicting factors, supportive role models scored the highest mean value. In view of this finding, it could be concluded that the necessity of having supportive role models is warranted when dealing with intention to pursue academic career.

The results were in line with Fouziah et al.' (2010), Fried and MacCleave's (2009), and Nauta and Kokaly's (2001) findings that a healthy relationship could transpire from the direct assistance of influential others (Gemme, 2005). Consequently, individuals will be ready to decide on a career. Moreover, Fauziah Nordin (2009) revealed that in collectivist society, such as Malaysia, this type of role models (supportive role models) who provides direct assistance is highly expected. Nauta and Kokaly (2001) asserted that some career choices need detailed information for one to make a decision to pursue. Academic career is one of the career choices. It is necessary for aspirations to get further information about academic career in order to successfully pursue the career. For example, individuals might want to be friends with some academicians so that they could get better information on which field or subject they should go for. In the course of time, individuals build a close relationship with their role models who will later furnish them with the right information as well as the right advice (Perrone et al., 2002).

Inspirational Role Models. Factor analysis showed that inspirational role models have some items from supportive role models. This variable has five items in which two of the items came from supportive role models and the other three items came from inspirational role models. All items indicated that none of the role models can provide direct assistance in matters about academic career choices. The internal consistency reliability showed a high Cronbach's alpha of 0.82 . This meant that the items in inspirational role models blended well as a measure. The mean value score of 3.37 indicated that this variable could exert influence on the intention to pursue academic career as well.

In brief, the current study which investigates individuals' intention to pursue academic career found that the relationship with supportive role models seems more relevant than from inspirational role models, particularly, among final year students (Lockwood \& Kunda, 1997). According to Lockwood and Kunda (1997), inspirational role model could produce greater effect among first year students only. However, as the students reach their final year, the students require role models who could guide them instantly when needed. In addition, individuals will be inspired only if individuals found the inspirational role models are motivating and inspiring in which the inspirational role models' accomplishments seemed attainabale (Lockwood \& Kunda, 1997). On this note, Walqui (2000) postulated that role model should be the one who can strongly affect individuals' desire and ability to learn more.

In view of this, supportive role modle would not only provide support but also act as mentor who is around when needed (MacCallum \& Beltman, 2002). According to MacCallum and Beltman (2002), mentoring has been known as the popular act of giving support and guidance. Supportive role models also offer strategies on how to be successful in the career chosen. For instance, in developing individuals' research skill which is relevant to successful academic career (Adedokun et al., 2011). In fact, Lent et al.' (1994) stated that attentive 


\section{IJBE}

International Journal of Business Economics, 1(1), 22-38, September 2019

http://jurnal.umsu.ac.id/index.php/ijbe

eISSN 2686-472X

learning from the relationship built with role models will enhance students' efficacy. Gibson (2004) revealed that the relationship built with role model could influence self-concept and provide learning, motivation, and inspiration. In addition, the role model not only provides general information on achieving the goal (becoming academician) but also show the path to achieve that goal. In short, the exposure to role model, in this case, the supportive role model, would increase the attainment of career aspiration as well (Nauta et al., 1998; Nauta \& Kokaly, 2001; Shapiro et al., 2013). Therefore, based on the argument about supportive role models, the items in supportive role models may become the appropriate measure in studying the career intention of academic career choices.

\section{Perceived Workplace Flexibility}

Perceived workplace flexibility refers to the degree in which individuals envisage the work arrangement in the career so that individuals are able to make choices to arrange the core aspects of their professional lives, particularly regarding where, when, and how long work is performed (Hill et al., 2008). Lu et al. (2008) defined the meaning of workplace flexibility as the consideration given by direct supervisor to entertain personal or family matters for an hour or two. The current researcher conceptualized the definition of perceived workplace flexibility mainly based on these two definitions. Since respondents are final year undergraduates, the current research defined perceived workplace flexibility as one's ability to perceive the choice that one has in arranging the core aspects of one's professional lives with regards to where, when, and how long work is performed (Hill et al., 2008) and time permitted to attend personal and family matters that can be considered by the employer (Lu et al., 2008).

\section{The Mediating Effects of Career Decision-Making Self-Efficacy}

This study attempts to examine the mediating effects of CDMSE's confidence to handle tasks on the relationship between each of the dimension of intention to pursue academic career (the dependent variable) and the motivating factors (the independent variables). The current study indicated that only CDMSE's confidence to handle task of assessing personal and occupational features, and CDMSE's confidence to handle task of gathering occupational information had a partial mediation effect. Meanwhile, CDMSE's confidence to handle task of making a realistic planning was not supported for having a mediation effect.

\section{The Mediating Effects of CDMSE's Confidence to Handle Task of Assessing Personal and Occupational Features}

CDMSE's confidence to handle task of assessing personal and occupational features partially mediated the relationship between passion and interest to pursue intention. This means that passion has both direct and indirect effect on interest to pursue intention when mediated by CDMSE's confidence to handle task of assessing personal and occupational features. In other words, the result implies that one may have passion in academic career, but one may still not follow through their intention to pursue the career unless one found the match between the characteristics or the aspects of the career, and one's expectation. As revealed by Gushe et al. (2006), individuals' confidence in performing the tasks is associated with the compatibility of the career to what individuals expect the career to be. In relation to that, the eleven items in CDMSE's confidence to handle task of assessing personal and occupational features, which recorded very significant factor loadings do measure the relevant aspects. Those items indicate the preference of individual to the characteristics of a particular job or career that will incite individual's interest to pursue the intention. In conclusion, the knowledge that one has 


\section{IJBE}

International Journal of Business Economics, 1(1), 22-38, September 2019

http://jurnal.umsu.ac.id/index.php/ijbe

eISSN 2686-472X

on the detail aspects of the career would increase or decrease one's preference of the career. Thus, the more knowledge that one has on the details of the career, the greater the interest to pursue intention would be, in which having passion alone would not determine the intention to pursue the career.

The other relationships that are partially mediated by CDMSE's confidence to handle task of assessing personal and occupational features include the relationship between passion and extrinsic importance attached to academic career, and the relationship between supportive role models and extrinsic importance attached to academic career. This means that both passion and supportive role models have a direct and indirect positive relationship with extrinsic importance attached to academic career when mediated by CDMSE's confidence to handle task of assessing personal and occupational features. Passion almost produced moderate effect of 29.1 per cent of variation in extrinsic importance attached to academic career, while, supportive role models exerted a small effect of 15.2 per cent. According to Cohen's (1988) conventions to interpret effect size, a correlation coefficient of .10 represents a weak or small association, a correlation coefficient of .30 represents a moderate correlation and a correlation coefficient of .50 or larger is thought to represent a strong or large correlation. These results revealed that the information on extrinsic benefits of academic career might lure one interest in pursuing the intention. Moreover, the reliance on role models to furnish the information about the extrinsic benefits could further enhance the intention to pursue the career. However, one may still not follow through one's intention to pursue academic career unless one is sure enough that there is compatibility between the occupational features and one's personal preference.

Indirectly, the results revealed that one's eagerness to pursue a career would become much higher if one knows the positive impact or the benefits that the career could bring to the society. In view of this, it could be interpreted that supportive role models might directly or indirectly affect one's intention to pursue academic career as a result of the extrinsic importance attached to academic career. It has become evident that for role models who share information about the interesting academic career with others such as through close research supervision or mentor-mentee program, these role models would least likely talk about the significant of other careers than academic career. As a consequence, this type of role models (role models with direct at influence) would incite individuals' interest in academic career. In addition, one could get the right information of the extrinsic importance attached to academic career related to academic career from role models who often interacts with students. Nevertheless, the partial mediation effect indicated that supportive role models would only provide the necessary information of extrinsic benefits if one sees common characteristics of the career and oneself.

\section{The Mediating Effects of CDMSE's Confidence to Handle Task of Gathering Occupational Information}

Current study revealed the impact of passion on interest to pursue intention as mediated by CDMSE's confidence to handle task of gathering occupational information. In addition, the study also exposed the impact of passion and supportive role models on extrinsic importance attached to academic career as mediated by CDMSE's confidence to handle task of gathering occupational information. This means that passion has both direct and indirect effect on interest to pursue intention when mediated by CDMSE's confidence to handle task of gathering occupational information. In other words, the result implies that one is unsure to fulfil the intention to pursue academic career just because of the passion in academic career. 


\section{IJBE}

International Journal of Business Economics, 1(1), 22-38, September 2019

http://jurnal.umsu.ac.id/index.php/ijbe

eISSN 2686-472X

However, if one found that there is enough information about the academic career one will pursue the intention seriously. When one is confident with the related information gathered about the academic career, one has the tendency to be more committed in pursuing the career (Anderson \& Gilbride, 2005). For instance, even though academician have been called to contribute more in research outputs, academic career is still closely related to having a flexible work schedule and arrangement. Apart from the core tasks of teaching and doing research, some challenges may appear in the form of administrative dissatisfaction (Haryani Haron et al., 2010). Thus, ability to perceive these issues and challenges could be known through the information gathered which may positively affect one's intention to pursue academic career. In short, information gathered about the career's challenges and issues would increase or decrease one's preference of the career. Thus, the more knowledge that one has on the career, the greater the interest to pursue intention would be in which having passion alone would not determine the intention to pursue the career.

The other relationships that were partially mediated by CDMSE's confidence to handle task of gathering occupational information include the relationship between both passion and supportive role models, and extrinsic importance attached to academic career. Passion produced an almost moderate effect (0.29) of variation in extrinsic importance attached to academic career, while, supportive role models exerted a small effect (15.1). These results revealed that the information on extrinsic benefits of academic career might lure one's interest in pursuing the intention. Moreover, the reliance on role models to furnish the information about the extrinsic benefits could further enhance the intention to pursue the career. However, one may still not follow through one's intention to pursue academic career unless one is sure enough that one is capable of perceiving all the issues and challenges related to academic career.

\section{The Rejection of Career Decision-Making Self-Efficacy's Confidence to Handle Task of Making a Realistic Planning}

The hierarchical regression analyses found impressive influence on CDMSE's confidence to handle task of assessing personal and occupational features and gathering occupational information. Nevertheless, CDMSE's confidence to handle task of making realistic planning was not supported as having a mediator effect on any of the dimension of intention to pursue academic career. This is due to the fact that items forming CDMSE's confidence to handle task of making realistic planning were mainly for those who already in a particular career. In addition to that, studies (such as Isik, 2010; Taylor \& Betz, 1983) revealed that majority of undergraduate students reported tasks on problem-solving as the most difficult one. Two of the items in CDMSE's confidence to handle task of making realistic planning are items that were derived from the problem solving scale of CDMSE's original scale (Betz, Klein, \& Taylor, 1996). Furthermore, the use of CDMSE's confidence to handle task of making realistic planning as a mediator in the current study could be revised since the respondents are considered very new to have a good knowledge about academic career in which respondents were asked on the possibility of changing a career that they are yet to decide on pursuing. In view of this, Creed et al. (2006) had suggested to assist young people in identifying their career goal, which is more appropriate rather than enhancing self-efficacy in the hope that it will reduce indecisiveness.

In general, CDMSE plays a vital role in career exploration behaviour. Only the CDMSE's confidence to handle task of making realistic planning is not certain since this dimension measure one's decision after entering a career. However, both CDMSE tasks of 


\section{IJBE}

International Journal of Business Economics, 1(1), 22-38, September 2019

http://jurnal.umsu.ac.id/index.php/ijbe

eISSN 2686-472X

assessing personal and occupational features, and gathering occupational information contributed to respondents in the current study in which it has a direct and indirect influence over intention to pursue academic career. Previous researches (Lent et. al, 1994; Sheu et. al, 2010) support the current finding.

\section{CONCLUSION}

The current research attempts to investigate the influence of some personal and contextual factors (passion, supportive role models, and perceived workplace flexibility) towards intention to pursue academic career. A mediator (career decision-making self-efficacy) is also introduced in the study. To date, conceptualisation on the intention to pursue a career in academics is still inconclusive and debatable. Nevertheless, Malaysia has continuously made known its aspiration to be one of the potential higher education providers in the region. Continuous efforts to yield more quality academic career aspirants are geared up. Passion, supportive role models, and perceived workplace flexibility were found to be significantly predicting intention to pursue academic career. Yet, perceived workplace flexibility was found to have less influence when compared to the other two variables. Meanwhile, career decision-making self-efficacy of assessing personal and occupational features and career decision-making self-efficacy of gathering occupational information were well reported to partially mediate the relationship of passion and supportive role models, and the criterion variable (intention to pursue academic career). As a result, a workable theoretical framework is proposed. In short, the current research provides a strong indication that in order to successfully produce future quality academics, the initial and most important step is to develop high intention among career prospects about the most promising academic career. For that reason, the decision taken by the researcher to merely investigate individuals representing Gen-Y who are currently enrolled in their final year of undergraduate study looks appropriate. This is to get immediate feedback and most accurate results knowing that 2020 is around the corner.

\section{REFERENCES}

Ahmad Nurulazam Md Zain, Aida Suraya Md Yunus, Ibrahim Che Omar, Morshidi Sirat, Munir Shuib, Rosni Bakar, \& Shukran Abdul Rahman. (2008). Sistem pendidikan tinggi dan model universiti di Malaysia: Pengisian. In M. Sirat (Ed.), Model Sistem Pendidikan Tinggi dan Universiti untuk Malaysia: Kerangka dan Pengisian. USM Penang: IPPTN.

Anderson, L. S., \& Gilbride, K. A. (2005). Image of engineering among Canadian high school students.The $8^{\text {th }}$ UICEE Annual Conference on Engineering Education, Kingston, Jamaica, 1-4.

Astin, H. S. (1984). The meaning of work in women's lives: A sociopsychological model of career choice and work behavior. The Counseling Psychologist, 12(4), 117-126.

Bakar, A. R., Zakaria, N. S., Mohamed, S., \& Hanapi, Z. (2011). Career decision-making selfefficacy of Malaysian vocational and technical students. International Journal of Arts \& Sciences, 4(16), 157-166.

Baron, R. M., \& Kenny, D. A. (1986). The moderator-mediator variable distinction in social psychological research: Conceptual, strategic and statistical considerations. Journal of Personality and Social Psychology, 51, 1173-1182. 


\section{IJBE}

International Journal of Business Economics, 1(1), 22-38, September 2019

http://jurnal.umsu.ac.id/index.php/ijbe

eISSN 2686-472X

Betz, N. E., Klein, K. L., \& Taylor, K. M. (1996). Evaluation of a Short Form of the Career Decision-Making Self-Efficacy Scale. Journal of Career Assessment, 4(1), 47-57. doi: 10.1177/106907279600400103.

Bobinski, D. (2009). Creating Passion-Driven Teams: How to Stop Micromanaging and Motivate People to Top Performance. NJ: Career Press

Boice, R. (2000). Advice for new faculty members: Nihil Nimus. Needham Heights, MA US: Allyn \& Bacon.

Brinkley, T. and Joshi, K. D. (2005) "Women in Information Technology: Examining the Role of Attitudes, Social Norms, and Behavioral Control in Information Technology Career Choices." WSU McNair Journal, 3, Fall 2005, 24-40, https:// research.wsulibs.wsu.edu:8443/ jspui/handle/ 2376/ 22, accessed on May 27, 2010.

Bruck, C. S., Allen, T. D., \& Spector, P. E. (2002). The relation between work-family conflict and job satisfaction: A finer-grained analysis. Journal of Vocational Behavior, 60, 336353.

Carbonneau, N., Vallerand, R. J., Fernet, C., \& Guay, F. (2008). The Role of Passion for Teaching in Intrapersonal and Interpersonal Outcomes. Journal of Educational Psychology, 100(4), 977-987. doi: 10.1037/a0012545

Cohen, JF. \& Parsotam, P. (2010) 'Intentions to Pursue a Career in Information Systems and Technology: An Empirical Study of South African Students', IFIP International Federation for Information Processing, 324, pp. 56-66

Coulehan, J. L. (2002). Being a physician: The physician's power. In M. B. Mengel, W. L. Holleman, \& S. A. Fields (Eds.), Fundamentals of clinical practice (2nd ed., pp. 7397). New York: Kluwer Academic/Plenum.Ching, K. M. (2010). Job vs. Career: JobStreet.com, Malaysia.

Court, S. (1999). Negotiating the Research Imperative: The Views of UK Academics on their Career Opportunities. Higher Education Quarterly, 53(1), 65-87.

Crites, J. O. (1968). Measurement of vocational maturity in adolescence. In D. G. Zytowski (Ed.). Vocational Behavior: Readings in theory and research (pp. 194-235). New York: Rinehart-Winston.

Day, C. (2004). A passion for teaching. London: RoutledgeFalmer.

Day, C. (2007). A passion for teaching. Paper presented at the A Public Lecture:, General Teaching Council for Northern Ireland, England.

Day, C., Sammons, P., Stobart, G., Kington, A., \& Gu, Q. (2007). Teachers Matter: Connecting Work, Lives and Effectiveness. Maidenhead: Open University Press.

Dlugos, R. F. \& Friedlander, M. L. (2001) Passionately Committed Psychotherapists: A Qualitative Study of Their Experiences. Professional Psychology: Research and Practice. 32(3), 298-304.

Drucker, P. F., \& Maciariello, J. A. (2004). The Daily Drucker. NY: HarperCollinsPublishers. Drucker, P. F., \& Maciariello, J. A. (2004). The Daily Drucker. NY: HarperCollinsPublishers.

Elhag, F. A. (2011).Current situation of higher education in the arab world and future scenarios. In Munir Shuib, Shukran Abd Rahman \& Aida Suraya Md Yunus (Eds.), Development of higher education and its future (pp. 85-106). Malaysia: IIUM Press \& IPPTN.

Elliot, B., \& Crosswell, L. (2002). Commitment to teaching: Australian perspective on the interplays of the professional and the personal in teachers' live. Paper presented at the 


\section{IJBE}

International Journal of Business Economics, 1(1), 22-38, September 2019

http://jurnal.umsu.ac.id/index.php/ijbe

eISSN 2686-472X

the International Symposium on Teacher Commitment at the European COnference on Educational Research, Lille, France.

Erikson, E. (1968). Identity: Youth and Crisis. New York: Norton.

Felton, S., Buhr, N., \& Northey, M. (1994). Factors influencing the business student's choice of career in chartered accountancy. Issues in Accounting Education, 9(1), 131-141.

Feltz, D. L., \& Payment, C. A. (2005). Self-efficacy beliefs related to movement and mobility. 2005 National Association for Kinesiology and Physical Education in Higher Education, 57, 24-36

Fieldt, R. C., Ferry, A., Bullock, M., Camarotti-Carvalho, A., Collingwood, M., Eilers, S., . . . Woelfel, C. (2010). Factorial Structure of the Career Decision Scale: Incremental Validity of the Five-Factor Domains. Measurement and Evaluation in Counseling and Development, 42(4), 235-245.

Fischman, W., Schutte, D. A., Solomon, B., \& Wu Lam, G. (2001). The development of an enduring commitment to service work. New Directions for Child and Adolescent Development, 93, 33-44.

Fouziah, M., Amla, M. S., \& Ramlee, M. (2010). The influence of contextual aspects on career decision making of Malaysian technical students. Procedia Social and Behavioral Sciences, 7(C), 369-375.

Fried. (2001). The passionate teacher: A practical guide (2 ed.). Boston: Beacon Press.

Fried\& MacCleave, A. (2009). Influence of Role Models and Mentors on Female Graduate Students' Choice of Science as a Career. Alberta Journal of Educational Research, 55(4), 482-496.

Goldacre, M.J., Turner, G., Fazel, S. and Lambert, T. (2005). Career choices for psychiatry: national surveys of graduates of 1974-2000 from UK medical schools. British Journal of Psychiatry, 186, 158-164.

Gore, P. A., \& Leuwerke, W. C. (2000). Predicting occupational considerations: A comparison of self-efficacy beliefs, outcome expectations, and person-environment congruence. Journal of Career Assessment, 8(3), 237-250.

Greenhaus, J. H., \& Beutell, N. J. (1985). Sources of conflict between work and family roles. Academy of Management Review, 10, 76-88.

Gushue, G. V, Clarke, C. P., Pantzer, K. M., \& Scanlan, K. R. (2006). Self-efficacy, perceptions of barriers, vocational identity, and the career exploration behavior of Latino high school students. The Career Development Journal, 54, 307-317.

Halpern, D.F. (2005). How time-flexible work policies can reduce stress, improve health, and save money. Stress and Health 21, 157-168.

Hartman, R. O. (2006). The Five-Factor Model and Career Self-Efficacy: General and Domain-Specific Relationships. A Dissertation Presented in Partial Fulfillment of the Requirements for the Degree Doctor of Philosophy. The Ohio State University. Ohio. Retrieved from http: //etd.ohiolink.edu/ send-pdf.cgi/ Hartman\%20Robert\%20Owen.pdf?osu1 147867278

Hill, E. J., Hawkins, A. J., Ferris, M., \& Weitzman, M. (2001). Finding an extra day a week: The positive influence of perceived job flexibility on work and family life balance. Family Relations, 50(1), 49-58.

Hill, E. J., Grzywacz, J. G., Allen, S., Blanchard, L. V., Matz-Costa, C., Shulkin, S., \& PittCatsouphes. (2008). Defining and conceptualizing workplace flexibility. Community, Work, \& Family, 11(2), 149-163. doi: 10.1080/13668800802024678 


\section{IJBE}

International Journal of Business Economics, 1(1), 22-38, September 2019

http://jurnal.umsu.ac.id/index.php/ijbe

eISSN 2686-472X

IPPTN. (2006). Laporan Model Universiti untuk Malaysia. In I. P. P. T. Negara (Ed.). Pulau Pinang: Universiti Sains Malaysia.

Isik, E. (2010). Career decision self-efficacy among Turkish undergraduate students. Electronic Journal of Research in Educational Psychology, 8 (2), 749-762.

Johnson, R.D., Stone, D.L., Phillips, T.N. (2008). Relations Among Ethnicity, Gender, Beliefs, Attitudes, and Intention to Pursue a Career in Information Technology. J. Appl. Soc. Psychol. 38(4), 999-1022

Lent, R. W., Brown, S. D., \& Hackett, G. (1994). Toward a unifying social cognitive theory of career and academic interest, choice, and performance. Journal of Vocational Behavior, 45(1), 79-122.

Levinson, D. J. (1996). The seasons of a woman's life. New York: Alfred Knopf.

Levinson, D. J., Darrow, C. N., Klein, E. B., Levinson, M. H., \& McKee, B. (1978). Seasons of a man's life. Englewood Cliffs, NJ: Prentice-Hall.

Lindholm, J. A. (2004). Pathways to the Professoriate: The Role of Self, Others, and Environment in Shaping Academic Career Aspirations. [Article]. Journal of Higher Education, 75(6), 603-635.

Lu, L., Kao, S.-F., Chang, T.-T., \& Wu, H.-P. (2011). Work/family demands, work flexibility, work/family conflict, and their consequences at work: A national probability sample in Taiwan. International Perspectives in Psychology: Research, Practice, Consultation, 1(S), 68-81. doi: 10.1037/2157-3883.1.S.68

Maleske, R. T. (1995). Foundations for Gathering and Interpreting Behavioral Data. Pacific Grove, CA: Brooks/Cole Publishing Company.

Ministry of Higher Education. (2007). The national higher education strategic plan: Laying the foundation beyond 2020. Kuala Lumpur: Ministry of Higher Education.

Ministry of Higher Education. (2008). Higher Education Statistics. Putrajaya: Ministry of Higher Education. Retrieved from http:// www.mohe.gov.my/ web_statistik/ Buku_Perangkaan_2008.pdf

Ministry of Higher Education. (2009). Higher Education Statistics. Putrajaya: Ministry of Higher Education. Retrieved from http:// www.mohe.gov.my/ web_statistik/ statistik_pdf_2009/04_BAB_2_IPTA.pdf

Ministry of Higher Education. (2010). Higher Education Statistics. Putrajaya: Ministry of Higher Education. Retrieved from http:// www.mohe.gov.my/ web_statistik/ perangkaan_2010.pdf

Ministry of Higher Education. (2011). Higher Education Statistics. Putrajaya: Ministry of Higher Education. Retrieved from http:// www.mohe.gov.my/ web_statistik/ perangkaan2011/ BAB1-IPTA.pdf

Ministry of Higher Education. (2012). Higher Education Statistics. Putrajaya: Ministry of Higher Education. Retrieved from http:// www.mohe.gov.my/ web_statistik/ Perangkaan_SPT_2012.pdf

Ministry of Higher Education. (2013). National Education Statistic: Higher Education Sector 2012. Planning, Research and Policy Coordination Division ( $1^{\text {st }}$ Ed.). Retrieved from http://www.mohe.gov.my/web_Statistik/ Perangkaan_SPT_2012.pdf

Mok, K. H., \& Yu, K. M. (2011). The quest for regional education hub status and transnational higher education: challenges for managing human capital in Asia. Asia Pasific Journal of Education, 31(3), 229-248. 


\section{IJBE}

International Journal of Business Economics, 1(1), 22-38, September 2019

http://jurnal.umsu.ac.id/index.php/ijbe

eISSN 2686-472X

Morshidi, S. (2005). "A Situation Analysis of Higher Education in Malaysia". Paper presented at a Regional seminar on Situation Analysis of Higher Education in Southeast Asia, 28-29 July 2005, Hanoi, Vietnam.

Nauta, M. M., \& Kokaly, M. L. (2001). Assessing role model influence on students' academic and vocational decisions. Journal of Career Assessment, 9, 81-99.

Norhasni Zainal Abidin, \& Mohd Rafaai Ayudin. (2008). Kerjaya Sebagai Pensyarah (2 ed.). Kuala Lumpur: PTS Professional.

Norshima Zainal Shah. (2008). Are graduates to be blamed? Unemployment of computer science graduates in Malaysia. http: //aabss.org/ Perspectives2008/ AABSS2008Article6 NORSHIMAZSHAH. Pdf

Patton, W. \& Creed, P. A. (2007). The relationship between career variables and occupational aspirations and expectations for Australian high school adolescents. Journal of Career Development, 34, 127-148.

Perrone, K. M., Zanardelli, G., Worthington, E. L., \& Chartrand, J. M. (2002). Role Model Influence on the Career Decidedness of College Students. [Article]. College Student Journal, 36(1), 109.

Quimby, J. L., \& DeSantis, A. M. (2006). The Influence of Role Models on Women's Career Choices. Career Development Quarterly, 54(4), 297-306.

Sekaran, U. (2003). Research methods for business: a skill building approach (4th edn.). John Wiley \& Sons, Inc.

Singh, N., Kaur, J., \& Schapper, J. \& Jack, G. (2013). The importance of place for international students' choice of university: a Malaysian case-study. In Frielick, S., BuissinkSmith, N., Wyse, P., Billot, J., Hallas, J. and Whitehead, E. (Eds.) Research and Development in Higher Education: The Place of Learning and Teaching, 36 (pp 326 - 335). Auckland, New Zealand, 1 - 4 July 2013)

Sneal, S. A. \& Dean, J. W. (1992). Integrated manufacturing and human resource management: A human capital perspective. Academy of Management Journal, 35 (3), 467-504.

Spector, P. E., Cooper, C. L., Poelmans, S., Allen, T. D., O’Driscoll, M., Sanchez, J. I., et al.(2004). A cross-national comparative study of work/family stressors, working hours, and well-being: China and Latin America vs. the Anglo world. Personnel Psychology, $57,119-142$.

Sumerlin, T. \& Littrell, J. (2011). The heart of the school counselor: Understanding passion over the span of a career. Processing School Counseling, 14(4), 278-285. April.

Super, D. E. (1957). The Psychology of Careers. New York: Harper.

Super, D. E. Work values inventory. Boston: Houghton, 1970.

Taylor, K., \& Betz, N. (1983). Applications of self efficacy theory to understanding the treatment of career indecision. Journal of Vocational Behavior, 22, 63-81.

Tham, S. Y., \& Kam, A. J. Y. (2007). Trade and investment linkages in higher education services in Malaysia. Retrieved from http:// www.unescap.org/ tid/artnet/ mtg/tipc_s2tham.pdf.

Vallerand, R. J., Blanchard, C. M., Mageau, G. A., Koestner, R., Ratelle, C. F., \& Leonard, M. (2003). Les passions de l'ame: On obsessive and harmonious passion. Journal of Personality and Social Psychology, 85, 756-767.

Vallerand, R. J., \& Houlfort, N. (2003). Passion at Work: Toward a New Conceptualization Emerging Perspectives on Values in Organizations (pp. 175-204): Information Age Publishing. 


\section{IJBE}

International Journal of Business Economics, 1(1), 22-38, September 2019

http://jurnal.umsu.ac.id/index.php/ijbe

eISSN 2686-472X

Yean, T.S. and A.K.J., Yi, (2007). Trade and investment linkages in higher education services in Malaysia. In ESCAP, Chapter VI, Towards coherent policy frameworks: understanding trade and investment linkages - A study by the Asia-Pacific Research and Training Network on Trade (pp.171-197). NY: United Nations.

Zulkifli Abd Rahman. (2014, April 13). We are working to improve the national system, says Muhyiddin. The Star Online. Retrieved from http:// m.thestar.com.my/ story.aspx?hl= We+are+working+to+improve+the+national+system+says+Muhyiddin\&sec=news\&id= \%7BDC3AAFB2-0675-4167-A428-6C11B26A70DE\%7D 